Goldschmidt 2021 Abstract

https://doi.org/10.7185/gold2021.3252

\section{Zircon trace element geochemistry and Ti-in-zircon thermometry of the Linté Pan-African post-collisional granitoids, Central Cameroon: Constraints on the genesis of host magma and tectonic implications}

PATRICK AYONTA KENNE ${ }^{1}$, SYLVESTRE GANNO ${ }^{2}$, TIMOLEON NGNOTUE ${ }^{1}$ AND JEAN PAUL NZENTI ${ }^{2}$

${ }^{1}$ University of Dschang

${ }^{2}$ University of Yaoundé

Presenting Author: ayontapatrick@yahoo.fr

The Linté area belongs to the central part of the AdamawaYadé Domain (AYD) within the Pan-African Central Africa Fold Belt (CAFB) in Cameroon. This area is dominated by Neoproterozoic high-K calc-akaline syenite and monzonite intruding Archean to Paleoproterozoic gneisses. In this contribution, trace element compositions of zircon obtained using LA-ICP-MS are used to constrain the petrogenesis and tectonic setting of Linté area. The analyzed zircon grains display restricted range of $\mathrm{Hf}$ content with an average of $8197 \mathrm{ppm}$ in syenite, $8220 \mathrm{ppm}$ in alkali-feldspar syenite, and $9026 \mathrm{ppm}$ in monzonite. They display high $\mathrm{Th} / \mathrm{U}$ ratios $(>0.5)$ typical of magmatic zircons. The monzonite zircons have a higher SREE content (483.42 ppm) than the syenite zircons (237.70 ppm). The chondrite-normalized REE diagram of Linté samples show very similar patterns, characterized by a steeply-rising slope due to important HREE enrichment relative to LREE, with distinctive positive $\mathrm{Ce}$ and negative Eu anomalies. Application of the Ti-inzircon thermometer to the analyzed zircons depicts a wide range of crystallization temperatures $\left(574-1137{ }^{\circ} \mathrm{C}\right.$ for syenites and $713-1008{ }^{\circ} \mathrm{C}$ for monzonite), implying a deep level of melting, likely within the lower continental crust of the CAFB. The integration of geochemical behaviors of some trace elements (U, $\mathrm{Hf}, \mathrm{Zr}, \mathrm{Ce}, \mathrm{Th}$ and $\mathrm{Nb}$ ), together with discrimination diagrams, suggest the crystallization of a continental crust derived magma under variable oxidation states, and emplacement in a magmaticarc setting. This finding conforms to the N-S geodynamic convergence model between the AYD and the northern border of the Congo Craton.
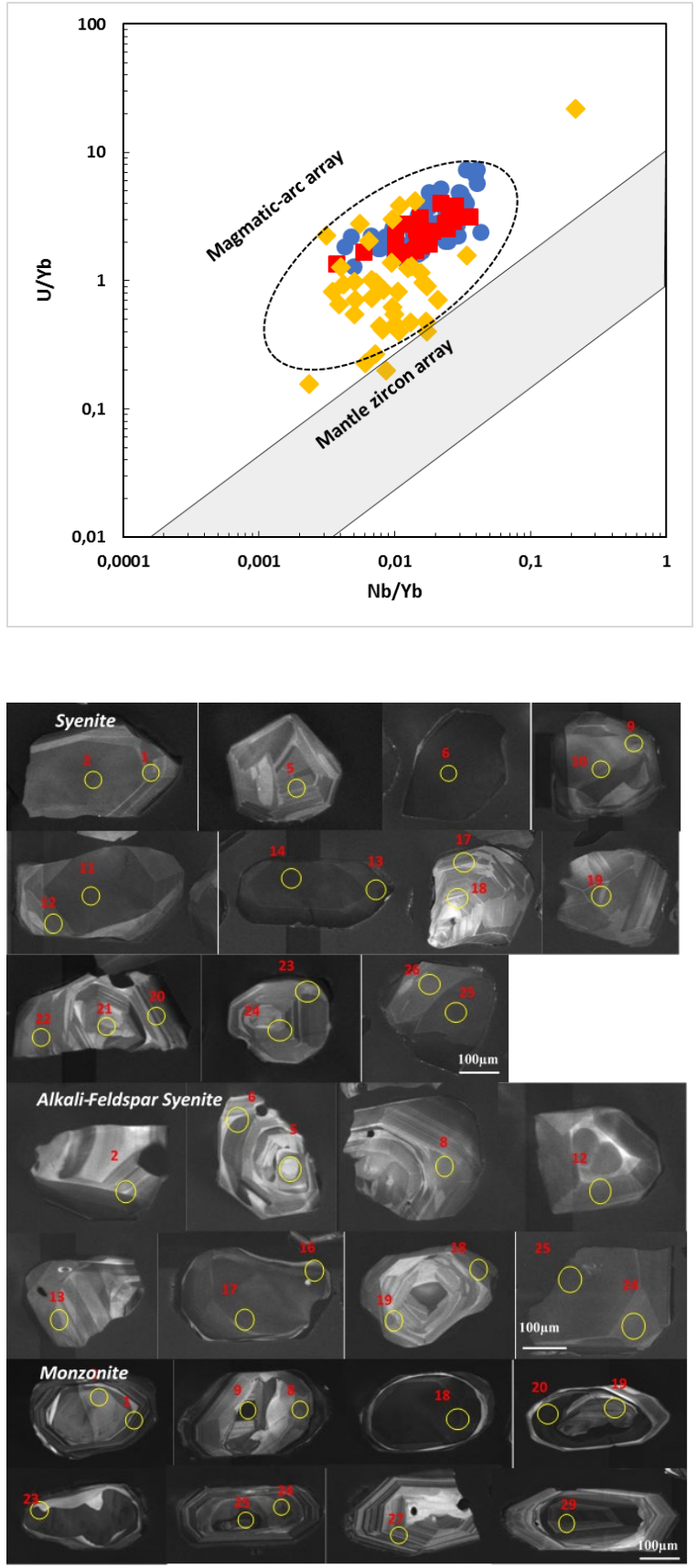